\title{
Settlement performance of the Mediterranean reef-builders Dendropoma cristatum (Biondi 1859) in response to natural bacterial films
}

\author{
Emanuela Claudia La Marca ${ }^{\mathrm{a}, \mathrm{b}, *}$, Valentina Catania ${ }^{\mathrm{c}}$, Paola Quatrini ${ }^{\mathrm{c}}$, Marco Milazzo ${ }^{\mathrm{a}, \mathrm{b}}$, \\ Renato Chemello ${ }^{\mathrm{a}, \mathrm{b}}$ \\ a Department of Earth and Marine Sciences, University of Palermo, Via Archirafi 22, 90123, Palermo, Italy \\ b Consorzio Interuniversitario per le Scienze del Mare (CoNISMa), Piazzale Flaminio 9, 00196, Roma, Italy \\ ${ }^{\mathrm{c}}$ Department of Biological, Chemical and Pharmaceutical Sciences and Technologies, University of Palermo, Viale delle Scienze, Ed.16, 90128, Palermo, Italy
}

\section{A R T I C L E I N F O}

\section{Keywords:}

Biological engineers

Reefs

Vermetidae

Mediterranean sea

Dendropoma cristatum

Settlement

Bacteria

Biological cues

\begin{abstract}
A B S T R A C T
The gastropod Dendropoma cristatum is a biogenic engineer of the central Mediterranean, forming reefs along the lower rocky intertidal fringe with a remarkable ecological role. To understand whether reef-associated biofilm cultivable bacterial and biofilm ageing may trigger the settlement of the juvenile snails, a combination of laboratory techniques and field experiments was used. Reef-associated biofilm cultivable bacteria were isolated, and a settlement-choice experiment was performed in situ on artificial biofilms composed of i) a mixture of six biofilm-forming selected isolates, ii) all the cultivable bacteria, and iii) 13-, 23-, 32-day old biofilms formed under natural conditions. Overall, settlement rate significantly differed among biofilm treatments $(\mathrm{p}<0.0001)$. A significant positive correlation between biofilm ageing and juvenile $D$. cristatum settlement was assessed ( $r=0.69$ ( $p<0.001)$, whereas the biofilm bacterial composition (relatively to the cultivable fraction) did not show any effect on the vermetid's settlement rate.
\end{abstract}

\section{Introduction}

Biogenic engineers (sensu Jones et al., 1997) are organisms which increase the physical complexity of habitats, driving the development of communities and enhancing species richness by reducing predation, competition and other bio-physical pressures (Bertness and Callaway, 1994; Bruno et al., 2003; Stachowicz, 2001). On the coastal zone, these organisms may build biogenic platforms with high horizontal development and three-dimensionality. These structures are called reefs and provide multiple ecosystem services, such as the production of economically relevant species, the reduction of the coastal erosion rates, carbon storage and nutrient and sediment cycling, among others (Barbier et al., 2011; Costanza et al., 1997; Crossland et al., 2005; Grabowski and Peterson, 2007). However, such habitats are currently subjected to increasing human pressure (Firth et al., 2015; Green et al., 2016) and their persistence is highly threatened by multiple factors of environmental degradation. An integrated approach to the management of these habitats and their reef-building species includes not only their active protection, but also plans for local restoration and population replenishment. Understanding biological mechanisms of reef formation and accretion is necessary for their successful conservation and restoration (Bertolini et al., 2017). Indeed, larval settlement of biogenic engineers is a critical phase during the reef build-up and for its local persistence. It is known that surface-specific cues may affect these complex dynamics (Pawlik, 1992; Phillips, 2011).

Intertidal vermetid bioconstructions are an example of these reefs and are made by gregarious gastropods and crustose coralline algae (Chemello, 2009; Laborel, 1987; Templado et al., 2016). Such habitats, typical of subtropical and warm temperate rocky coasts around the world (Milazzo et al., 2016), are mostly built-up by the gastropods Dendropoma spp. within the Mediterranean Sea (Golding et al., 2014; Safriel, 1966). Recent phylogenetic analyses revealed the existence of at least four cryptic species responsible for the creation of these bioconstructions, with a well-defined distribution in a west-east direction (Calvo et al., 2009, 2015; Templado et al., 2016). According to Golding et al. (2014), the four Mediterranean species are ecologically equivalent and show few morphological differences at the adult stage, but distinct developmental characters (e.g., egg capsule number, number of eggs per capsule) (Calvo et al., 1998). The embryonic and larval development are typically intracapsular and lecithotrophic, with metamorphosed hatchlings usually crawling out the maternal shell and settling nearby to start a sessile life (Templado et al., 2016). Mediterranean

\footnotetext{
* Corresponding author. Department of Earth and Marine Sciences, University of Palermo, Via Archirafi 22, 90123, Palermo, Italy.

E-mail addresses: emanuelaclaudia.lamarca@unipa.it (E.C. La Marca), valentina.catania@unipa.it (V. Catania), paola.quatrini@unipa.it (P. Quatrini), marco.milazzo@unipa.it (M. Milazzo), renato.chemello@unipa.it (R. Chemello).
} 
vermetid reefs have been facing increasing local decline in the last few decades (Galil, 2013; Rilov, 2016), and it is that likely insufficient protection measures are presently underway (Chemello, 2009; Chemello et al., 2014). Moreover, recent field experiment performed in Sicily and in Israel documented a significantly lower settlement rate of $D$. cristatum under ocean acidification levels and reduced photosynthetic and calcification performance of the associated red algae Neogoniolithon brassica-florida due to elevated temperature and $\mathrm{pH}$ decrease (Fine et al., 2016; Milazzo et al., 2014). These researches suggest that vermetid reefs persistence is at high risk in future ocean. Despite being crucial for the reef formation and stability and for ensuring its local persistence (Menge, 2000; Underwood et al., 1983), to date studies on settlement and recruitment of the Mediterranean Dendropoma spp. are scant. Temporal pattern of recruitment for the central Mediterranean $D$. cristatum has been described by Franzitta et al. (2016), which recorded consistent differences during the breeding season and between the inner and the outer reef rims. The authors suggested that physical and environmental conditions that characterize the two rims may affect the settlement success and post-settlement mortality of settlers, being responsible for the observed within-reef differences.

It is also established that several biological cues may trigger settlement of many benthic invertebrates (Crisp, 1974; Hadfield and Paul, 2001; Pawlik, 1992; Spotorno-Oliveira et al., 2015) and among these, microbial films, namely biofilms, have been identified as highly suitable layers for the settlement of a wide range of marine organisms (Hadfield, 2011; Sneed et al., 2014; Thompson et al., 1998; Toupoint et al., 2012; Zardus et al., 2008). Biofilms are typically made by bacteria, diatoms and others microscopic organisms embedded in a self-produced extracellular polymeric substance (EPS) and develop on all wet surfaces, increasing in density and structural complexity over the time (Donlan, 2002; Hadfield and Paul, 2001). These layers provide a complex of physical and biochemical stimuli which cue the settlement of a variety of bioengineer species, including mollusks (Satuito et al., 1997; Tamburri et al., 2008; Toupoint et al., 2012; Wahl, 1989). However, to date, no studies have been conducted to understand the potential biofilm-associated settlement for the reef-builder Dendropoma spp.

To increase knowledge of the key factors influencing the early steps of Dendropoma reef formation and to verify whether positive biological interactions may enhance spatial colonization by these gregarious gastropods, this study aims at assessing the influence of the biofilm bacterial composition and biofilm maturity on the settlement rate of the central Mediterranean reef-builders Dendropoma cristatum. To achieve this goal we coupled a settlement-choice experiment using reef-associated biofilm cultivable bacteria with one using the natural biofilm at different maturity stages. Such information will be valuable to shed light on mechanisms fostering settlement by the reef-building Dendropoma cristatum, potentially ensuring viable reef formation and temporal persistence.

\section{Materials and methods}

\subsection{Study area}

A field experiment was carried out during the summer 2016, in the locality Marina di Cinisi (NW of Sicily, Fig. 1).

Here, vermetid reefs develop on an intertidal carbonatic quaternary sub-flat platform exposed to the dominant wind from NW. The area is not protected under any legislation and during the summer is moderately frequented by tourists and fishers (E.C. La Marca, personal observation).

The experiment was performed in two different sites spaced $100 \mathrm{~m}$ apart $\left(38.191850^{\circ} \mathrm{N}, 13.119205^{\circ} \mathrm{E}\right.$ and $\left.38.191395^{\circ} \mathrm{N}, 13.121123^{\circ} \mathrm{E}\right)$, where a continuous vermetid reef is located along $176 \mathrm{~m}$ of coastline and characterized by complex outer (ca. $348 \mathrm{~m}$ long) and inner margins (ca. $284 \mathrm{~m}$ long). No detrimental signs of reef degradation, other than very few and limited areas $(<30 \mathrm{~cm})$ on the outer rim, are evident in

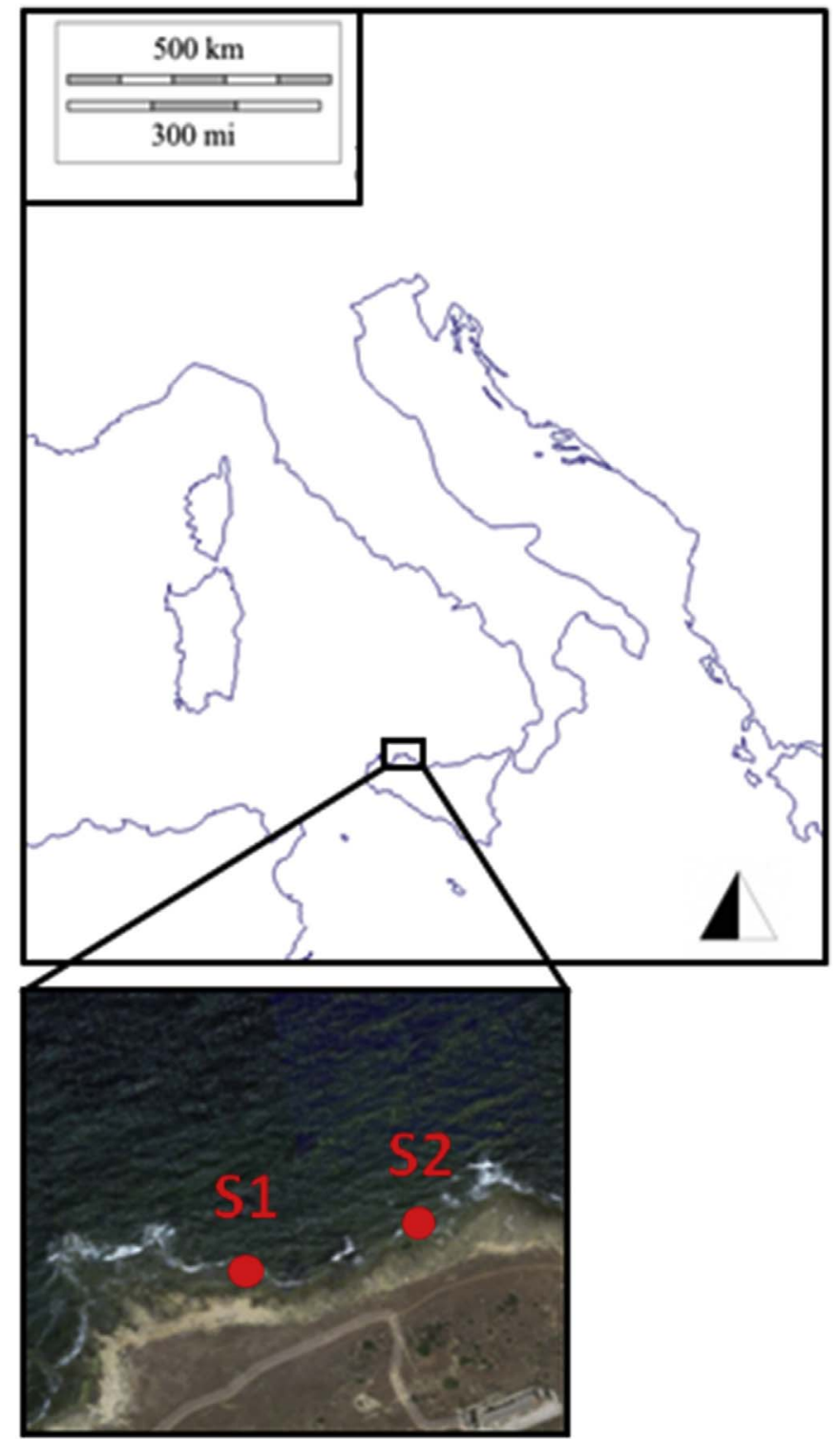

Fig. 1. Study area, S1 and S2 indicate the two sites where the field experiment was carried out.

this location, thus suggesting very low anthropogenic disturbance.

\subsection{Isolation of the reef-biofilm bacteria}

Aiming at identifying the presence of settlement-inducing bacterial taxa, reef-associated biofilm bacteria were identified by a culture-dependent approach by using Marine Agar plates (Pronadisa Laboratories, CONDA), a culture medium designed for isolation and enumeration of hetherotrophic marine bacteria (Sharp et al., 2015; Vieira et al., 2016; Webster et al., 2011). Biofilms were sampled by swabbing a $25 \mathrm{~cm}^{2}$ area on the surface of the $D$. cristatum aggregation on the outer margin of the reef within both the sites with cotton swabs. The swabs were streaked on Marine Agar plates and incubated at $25^{\circ} \mathrm{C}$. After incubation, all colonies showing different phenotypes were selected and transferred to fresh Marine Agar and incubated under the conditions described above. The procedure was repeated to obtain pure cultures. Aliquots of bacterial cultures were stored with glycerol ( $20 \%$ final concentration) at $-80^{\circ} \mathrm{C}$ for further characterization.

The 16S rRNA gene of the isolates was amplified by colony PCR. The amplification reaction was performed by using the universal forward 
primer Bac27_F and reverse primer Uni_1492R (Catania et al., 2015). Reaction mixtures contained OneTaq Standard Reaction Buffer 1X (New England Biolabs), $0.2 \mathrm{mM}$ of dNTPs mixture (Invitrogen), $200 \mathrm{nM}$ of forward and reverse primers, $1 \mathrm{U}$ of OneTaq DNA Polymerase (New England Biolabs) and $1 \mu \mathrm{l}$ of colony TE lysate. The following PCR conditions were used: an initial denaturation step at a $94^{\circ} \mathrm{C}$ for $3 \mathrm{~min}$, 30 cycles of $45 \mathrm{~s}$ at $94^{\circ} \mathrm{C}, 60 \mathrm{~s}$ at $50^{\circ} \mathrm{C}$, and $90 \mathrm{~s}$ at $72{ }^{\circ} \mathrm{C}$; a final extension step at $72{ }^{\circ} \mathrm{C}$ for $10 \mathrm{~min}$. The PCR amplification products were separated by $1 \%$ agarose gel electrophoresis and stained with ethidium bromide $1 \%$.

The 16S rDNA PCR products were restriction-enzyme digested with AfaI (New England Biolabs) as recommended by the manufacturer. Restriction digests were analyzed on 1.5\% agarose gel, and the resulting restriction patterns were used to assign the isolates to operational taxonomic units (OTUs) (Catania et al., 2017). One representative isolate of each OTU was selected for taxonomic identification, by 16S rRNA PCR product sequencing. The sequences were compared to the EMBL/SwissProt/GenBank rRNA_typestrains/prokaryotic 16SribosomalRNA database using Mega BLAST algorithm (http://blast.ncbi.nlm.nih.gov/ Blast. cgi) and the Naïve Bayesian rRNA Classifier Version 2.8, of the Ribosomal Database Project II (RDP) (Cole et al., 2014). The 16S rRNA sequences were deposited in the GenBank database under the accession numbers: MF522823-28MF522823MF522824MF522825MF522826MF522827MF522828.

\subsubsection{Quantification of biofilm production}

For each isolate, the ability to form a biofilm was assessed in plastic microtiter plates, as described by Stepanović et al. (2004) with slight modifications. A single colony of each isolate was transferred to $3 \mathrm{ml}$ of marine broth (MB) medium and incubated overnight at $30^{\circ} \mathrm{C} .20 \mu \mathrm{l}$ of bacterial culture were added to each well of a sterile 96-well flat-bottomed polystyrene micro-plate containing $230 \mu \mathrm{l}$ of MB and incubated for $24 \mathrm{~h}$ at $30^{\circ} \mathrm{C}$. Each strain was tested in triplicate. The bacterial culture was poured off and the wells washed four times with sterile distilled water. The attached bacteria were fixed by incubation for 15 min with $200 \mu$ l of methanol and stained with the same quantity of Crystal violet (2\%, used for Gram staining) for $5 \mathrm{~min}$. The wells were rinsed under water and the adherent cells were re-suspended in $250 \mu \mathrm{l}$ of $33 \%$ glacial acetic acid. Biofilm production ability was quantified directly by spectrophotometric readings at $570 \mathrm{~nm}$ using a Spark $10 \mathrm{M}$ multimode microplate reader (Tecan, Switzerland). Based upon the optical density of the bacterial films (ODs) and the optical density of a negative control (ODc), biofilm production ability of each strain was classified into the following categories: absent (ODs $\leq$ ODc), weak (ODc $<$ ODs $\leq 2 \times$ ODc), moderate $(2 \times$ ODc $<$ ODs $\leq 4 \times$ ODc $)$, strong $(4 \times$ ODc $<$ ODs).

\subsection{Settlement-choice experiment}

\subsubsection{Limestone block preparation}

The settlement rate of Dendropoma cristatum was surveyed in situ using limestone blocks $(5 \times 5 \times 2 \mathrm{~cm})$ as a substrate. This limestone belonged to the Marsala Synthem, a Lower Pleistocene marine/coastal deposit along the Palermo plain (Sicily) and was a cemented bioclastic calcarenite rich in invertebrate fossils, including vermetids (Di Maggio et al., 2009; Basilone and Di Maggio, 2016; Agate et al., 2017). Before running the settlement-choice experiment, freshly cut limestone blocks were autoclave sterilised and conditioned either by exposure to bacterial isolates in the laboratory or by exposure to natural conditions in the field. See below for a detailed description.

2.3.1.1. Laboratory conditioning. A subset of limestone blocks was prepared in the laboratory by incubation in two different culture broths: one including six isolates, each representative of each identified OTUs and chosen among those showing strong or moderate biofilm production ability (a mixture of the best Biofilm Former selected isolates, $\mathrm{BF}$ ); one containing all the 28 bacterial isolates cultured from the vermetid reef-associated biofilm (Total Isolates, TI). For the BF treatment, a liquid pre-culture was prepared by inoculating one colony of each selected bacterial isolate in $3 \mathrm{ml}$ of $\mathrm{MB}$ and incubating at $25^{\circ} \mathrm{C}$ overnight in a shaker at $200 \mathrm{RPM}$. One $\mathrm{ml}$ of each pre-culture was transferred into a $50 \mathrm{ml}$ of $\mathrm{MB}$ and incubated overnight under the same conditions. The mixed cultures were prepared by adding all $50 \mathrm{ml}$ culture in a 21 flask adding $\mathrm{MB}$ to $500 \mathrm{ml}$ and $500 \mathrm{ml}$ of autoclaved marine water.

For the TI treatment, the total bacterial isolates were cultivated as described above and the mixed culture was prepared by adding $10 \mathrm{ml}$ of each culture in a 21 flask, adding $\mathrm{MB}$ to $500 \mathrm{ml}$ and then $500 \mathrm{ml}$ of autoclaved marine water. Limestone blocks were totally submerged in the culture broths and incubated for $48 \mathrm{~h}$.

2.3.1.2. Field conditioning. Another subset of limestone blocks was prepared in the field, allowing the formation of natural biofilms of increasing maturity. To simultaneously run the settlement experiment across multiple biofilm age treatments, 3 groups of limestone blocks were deployed in the field in a staggered manner, gaining the development of a 32-, 23- and 13-day old biofilm. The blocks were randomly attached to the outer margin of the vermetid reef (Fig. 2 gives an example of the block spatial arrangement) using steel screws and, to prevent vermetid colonization during field exposure, the blocks were covered with a $0.2 \mathrm{~mm}$ mesh fabric.

\subsubsection{Field experiment}

Previous studies showed a low settlement competence of $D$. cristatum juveniles under laboratory conditions (unpublished data, La Marca, 2015). Therefore, the average settlement rate of Dendropoma cristatum was recorded in the field, in two sites on a range of conditioned blocks from lab and field conditions. Within each site, 8 replicated groups consisting of 6 interspersed biofilm treatments, i.e. the mixture of the best biofilm former selected isolates (BF), Total Isolates (TI), 32-day, 23-day, 13-day and 0-day old (a sterilised control with no biofilm), were fastened on the outer edge of the reef (Fig. 2 and Table 1), previously described as the portion of a vermetid reef with the highest settlement success (Franzitta et al., 2016). During field deployment, the blocks were carefully handled by means of sterile gloves and limiting the contact with their sides, aiming to do not contaminate or disturb the biofilm on the top face of the blocks. Within each site the groups of the six biofilm treatments were spaced apart around $80-100 \mathrm{~cm}$.

A total of 96 blocks was included and analyzed for settlement of $D$. cristatum after 5-day exposure to natural conditions (between August the 5th and the 10th 2016, because the higher number of recruits on the outer margin was observed in July and August, Franzitta et al., 2016).

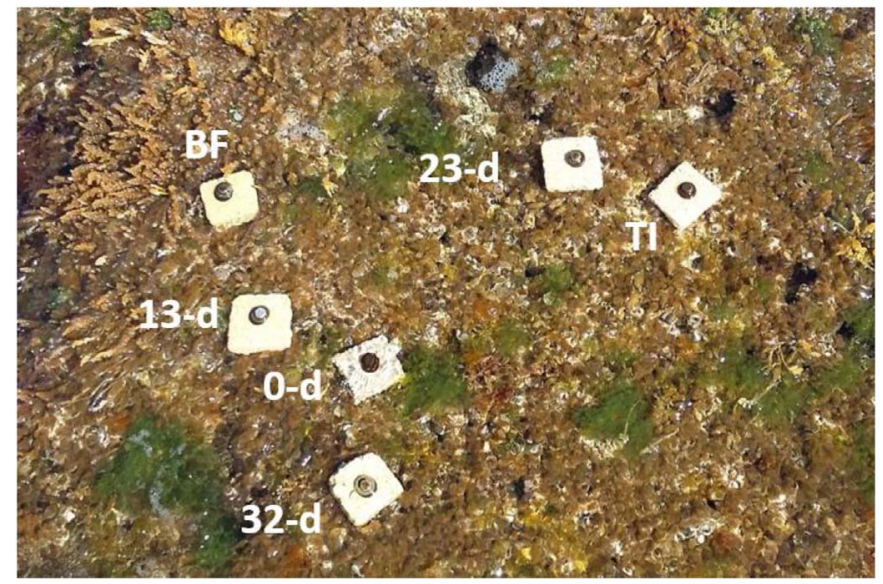

Fig. 2. Group of the 6 interspersed biofilm treatments used during the field experiment 
Table 1

Biofilm treatments used during the settlement experiment, their preparation and no. of replicates collected after the experiment.

\begin{tabular}{|c|c|c|c|}
\hline $\begin{array}{l}\text { Biofilm } \\
\text { treatments }\end{array}$ & Biofilm typology & Preparation & $\begin{array}{l}\text { No. of } \\
\text { replicates }\end{array}$ \\
\hline $0-d$ & Absent & autoclaved & 16 \\
\hline 13-d & 13-day old & in the field & 15 \\
\hline $23-d$ & 23-day old & in the field & 14 \\
\hline $32-\mathrm{d}$ & 32-day old & in the field & 16 \\
\hline TI & $\begin{array}{l}\text { Total bacterial isolates } \\
\text { from the reef }\end{array}$ & $\begin{array}{l}\text { Incubation in the } \\
\text { lab }\end{array}$ & 15 \\
\hline $\mathrm{BF}$ & $\begin{array}{l}\text { Mixture of the best biofilm } \\
\text { forming selected isolates } \\
\text { from the reef }\end{array}$ & $\begin{array}{l}\text { Incubation in the } \\
\text { lab }\end{array}$ & 13 \\
\hline
\end{tabular}

After exposure, the whole set of blocks was collected and the number of settled $D$. cristatum was scored under a microscope. For each biofilm treatment, the settlement rate was expressed as the average number of settled juveniles on $25 \mathrm{~cm}^{2}$ during 5 days. Since biofilms mainly developed on the top face of the blocks, only vermetid settlers recorded on this side were considered for the analysis.

\subsection{Statistical analysis}

Settlement data were not transformed for the statistical analysis and were ordinated using the Euclidean Distance. Univariate PerMANOVA was performed with two factors, unrestricted permutation of raw data, 9999 permutations and Monte Carlo test. The factor Biofilm ("Bi") was treated as fixed with 6 levels: 32-d, 23-d, 13-d, 0-d, BF and TI, and the factor Site ("Si") was treated as an orthogonal factor, with 2 levels: S1 and S2 (Site 1 and Site 2).

An a posteriori pair-wise comparison among pairs of levels within the factor Biofilm was also done. Analyses were performed by Primer v.6.

The relationship between the biofilm ageing and the average settlement rate of $D$. cristatum settlers was tested by a linear regression analysis.

\section{Results}

\subsection{Isolation of the reef-biofilm bacteria and quantification of biofilm production}

A total of 100 isolates was obtained from the vermetid reef-associated biofilm from both the sites. Among these, 28 morphologically different colonies were analyzed by amplified rDNA restriction analysis (ARDRA). Strains having overlapping restriction patterns were assigned to the same operational taxonomic unit (OTU). Six operational taxonomic units were identified and affiliated to Proteobacteria (96\%) and Bacteroides (4\%). 16S gene sequencing of one representative of each OTU revealed the presence of the following species: Alteromonas genovensis, Pseudoalteromonas tetraodonis, Shewanella pneumatophore, Vibrio alginolyticus, Vibrio gigantis and Cellulophaga lytica (Table 2).
Table 3

Biofilm production ability of the isolates within each OTU, classified as strong, moderate, weak or absent (\% of the total isolates). BF:a mixture of the best biofilm former selected isolates.

\begin{tabular}{|c|c|c|c|c|c|c|}
\hline \multirow[t]{2}{*}{ OTUs } & \multirow{2}{*}{$\begin{array}{l}\text { No. of } \\
\text { isolates/ } \\
\text { OTU }\end{array}$} & \multicolumn{4}{|c|}{ Biofilm production ability (\%) } & \multirow{2}{*}{$\begin{array}{l}\text { Representative } \\
\text {-isolate used in the BF } \\
\text { treatment }\end{array}$} \\
\hline & & Strong & Moderate & Weak & Absent & \\
\hline A & 6 & 16.66 & 66.66 & 16.66 & 0 & P2 2.2 \\
\hline B & 7 & 71.42 & 28.57 & 0 & 0 & P8 4.1 \\
\hline $\mathrm{C}$ & 1 & 0 & 0 & 0 & 100 & P7 2.4b \\
\hline $\mathrm{D}$ & 1 & 0 & 100 & 0 & 0 & P7 2.4a \\
\hline $\mathrm{E}$ & 1 & 0 & 100 & 0 & 0 & P3 2.2 \\
\hline $\mathrm{F}$ & 12 & 75 & 8.33 & 8.33 & 8.33 & P5 2.3 \\
\hline TOT & 28 & 54 & 32 & 7 & 7 & \\
\hline
\end{tabular}

Biofilm production ability was assessed for all the 28 isolates and revealed that almost all the strains were able to originate a biofilm (Table 3). The biofilm production was strong for the $54 \%$ of the strains, moderate for the $32 \%$, weak for the $7 \%$ and absent for the $7 \%$ (Table 3 ).

\subsection{Settlement choice experiment}

During field conditioning of the limestone blocks, the successively longer ageing periods produced greater greening on their upper surfaces, likely as a consequence of a progressively greater microbial colonization, probably including (Cyano)bacteria, algae and other microscopic organisms (Fig. 3).

Despite the loss of 7 blocks during the field experiment, $126 \mathrm{D}$. cristatum settlers were counted on the top face of the remaining blocks ( $\mathrm{n}=89$ ), 63 belonging to site 1 and 63 to site 2 . Settlement occurred on each biofilm treatment, although within site 1 no settlers were found on the sterilised blocks (0-d).

The average settlement rate ( \pm S.E.) recorded after 5 days ranged from 0 to 4.87 ind. $/ 25 \mathrm{~cm}^{2}$ ( \pm 0.95 ), significantly differed among the 6 biofilm treatments (PerMANOVA; $\mathrm{p}<0.001$ ), and, importantly, was similar between sites (Fig. 4, Table 4).

The increase of the biofilm maturity from 0- up to 32-days resulted in a progressively higher average settlement rate on field conditioned blocks. Moreover, settlement rate was low on the laboratory conditioned blocks (BF and $\mathrm{TI}$ ) and on sterilised controls (0-d), with, on average, less than 1 settler $/ 25 \mathrm{~cm}^{2}$ after 5 days (Fig. 4). Specifically, 32$\mathrm{d}$ and 23-d biofilms differed from all the treatments and each other and the two laboratory cultured biofilms, BF and TI, did not show any difference with the 0 -d biofilms. (Table 5).

Focusing on the number of $D$. cristatum individuals settling on field conditioned blocks throughout the experimental period, we found a positive relationship between biofilm maturity and settlement rates $(\mathrm{r}=0.69, \mathrm{p}<0.001 ; \mathrm{n}=61$, Fig. 5).

\section{Discussion}

Our field experiment clearly documented for the first time that the settlement performance of the Mediterranean ecosystem engineer

Table 2

Identity of each identified bacterial isolate through aligned and annotated rRNA gene sequence data.

\begin{tabular}{|c|c|c|c|c|c|c|}
\hline \multicolumn{7}{|c|}{ Classifier Version (Ribosomal Database Project, RDPII) } \\
\hline Phylum & class & family & OTU & Closest sequence match & Id $(\%)$ & Accession number \\
\hline Proteobacteria & Gammaproteobacteria & Alteromonadaceae & A & Alteromonas genovensis & 98 & NR_042667.1 \\
\hline Proteobacteria & Gammaproteobacteria & Pseudoalteromonadaceae & $\mathrm{F}$ & Pseudoalteromonas tetraodonis & 99 & NR_114187.1 \\
\hline Proteobacteria & Gammaproteobacteria & Shewanellaceae & $\mathrm{D}$ & Shewanella pneumatophori & 99 & NR_041292.1 \\
\hline Proteobacteria & Gammaproteobacteria & Vibrionaceae & $\mathrm{B}$ & Vibrio alginolyticus & 99 & NR_122059.1 \\
\hline Proteobacteria & Gammaproteobacteria & Vibrionaceae & $\mathrm{C}$ & Vibrio gigantis & 99 & NR_044079.1 \\
\hline Bacteroidetes & Flavobacteriia & Flavobacteriaceae & $\mathrm{E}$ & Cellulophaga lytica & 100 & NR_074464.1 \\
\hline
\end{tabular}



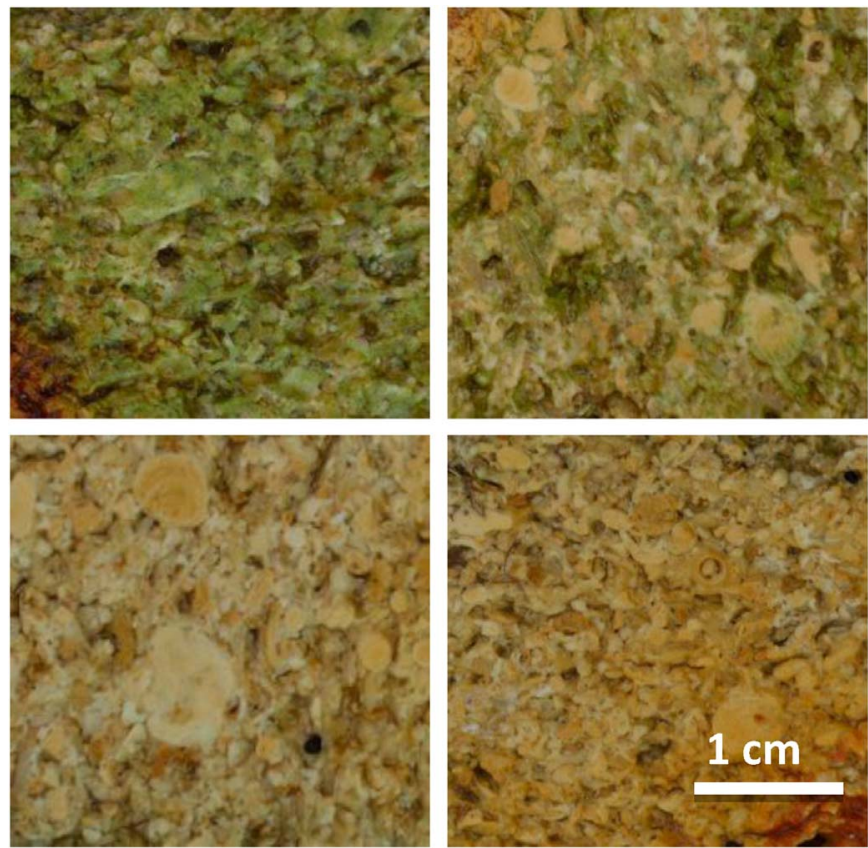

Fig. 3. Photographic panel of the microbial colonization on field-conditioned limestone blocks after 32-, 23- and 13-days of field exposure (in clockwise, respectively), and a sterilised block (bottom left picture), showing an evident greening of the surface.

Dendropoma cristatum is influenced by the reef-associated biofilm, and the effect progressively increases with days of development of the microbial layer. Crawling juveniles of $D$. cristatum did not settle in response to the 0 -d biofilm treatment, and their settlement rate was substantially enhanced on older biofilms, as the mean number of settlers was 17-fold higher from the 0- to 13-d, 2.3 times from 13- to 23-d and of 1.75 fold from 23- to 32-d of maturity, respectively.

These results are consistent with the evidence that the settlement of invertebrate larvae usually increases with biofilm age, with young biofilms being less inductive than more developed microbial assemblages (Keough and Raimondi, 1995, 1996). Globally, settlement
Table 4

PerManova analysis of the D. cristatum settlement success for the factor biofilm, "Bi" (fixed with 6 levels) and site, "Si" (orthogonal, with 2 levels). A posteriori pairs-wise comparisons within the factor Biofilm showed a significant effect of the biofilm maturity on the settlement rate of Dendropoma cristatum (Table 5).

\begin{tabular}{lllll}
\hline Source & df & MS & Pseudo-F & P (perm) \\
\hline $\mathrm{Bi}$ & 5 & 44.085 & 22.245 & 0.0001 \\
$\mathrm{Si}$ & 1 & 0.0005 & 0.00027 & 0.9878 \\
$\mathrm{BixSi}$ & 5 & 1.7268 & 0.8713 & 0.5067 \\
Res & 77 & 1.9818 & & \\
Total & 88 & & & \\
\hline
\end{tabular}

Table 5

Pair-wise comparisons within the factor Biofilm. Only significant differences are reported.

\begin{tabular}{ll}
\hline \multicolumn{2}{l}{ Pair-wise test for the term "Bi" } \\
\hline Groups & P (MC) \\
\hline 32-d, 23-d & 0.0243 \\
32-d, 13-d & 0.0002 \\
32-d, 0-d & 0.0001 \\
32-d, BF & 0.0001 \\
32-d, IT & 0.0001 \\
23-d, 13-d & 0.0393 \\
23-d, 0-d & 0.0001 \\
23-d, BF & 0.0002 \\
23-d, TI & 0.0001 \\
13-d, 0-d & 0.0241 \\
13-d, TI & 0.0454 \\
\hline
\end{tabular}

enhancement occurs on biofilms older than 1 week and this response may be related to biofilm density, as reported for tropical reef sponge, mussel and coral larvae (Toupoint et al., 2012; Webster et al., 2005; Whalan and Webster, 2014), but also to biofilm composition and species-specific interactions (Keough and Raimondi, 1996; Olivier et al., 2000; Qian et al., 2007; Wieczorek and Todd, 1998).

It is known that the settlement performance in response to biofilm composition may exert selective aspects, being different among potential settlers. In our study a significantly lower settlement rate was

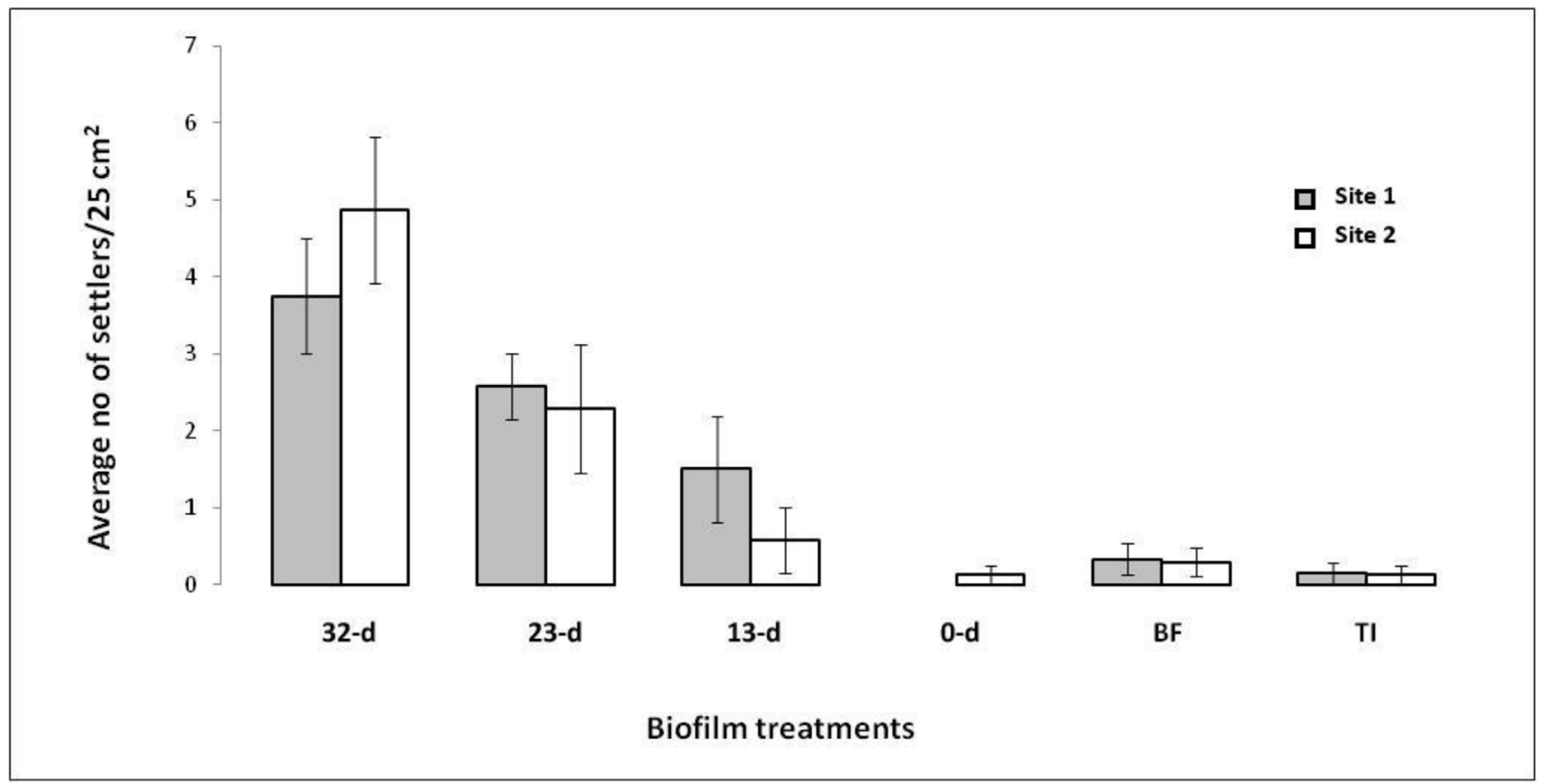

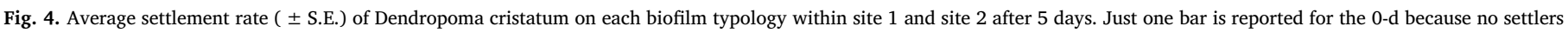
were found on this treatment within site 1. BF: the mixture of the best biofilm forming selected isolates; TI: total isolates. 


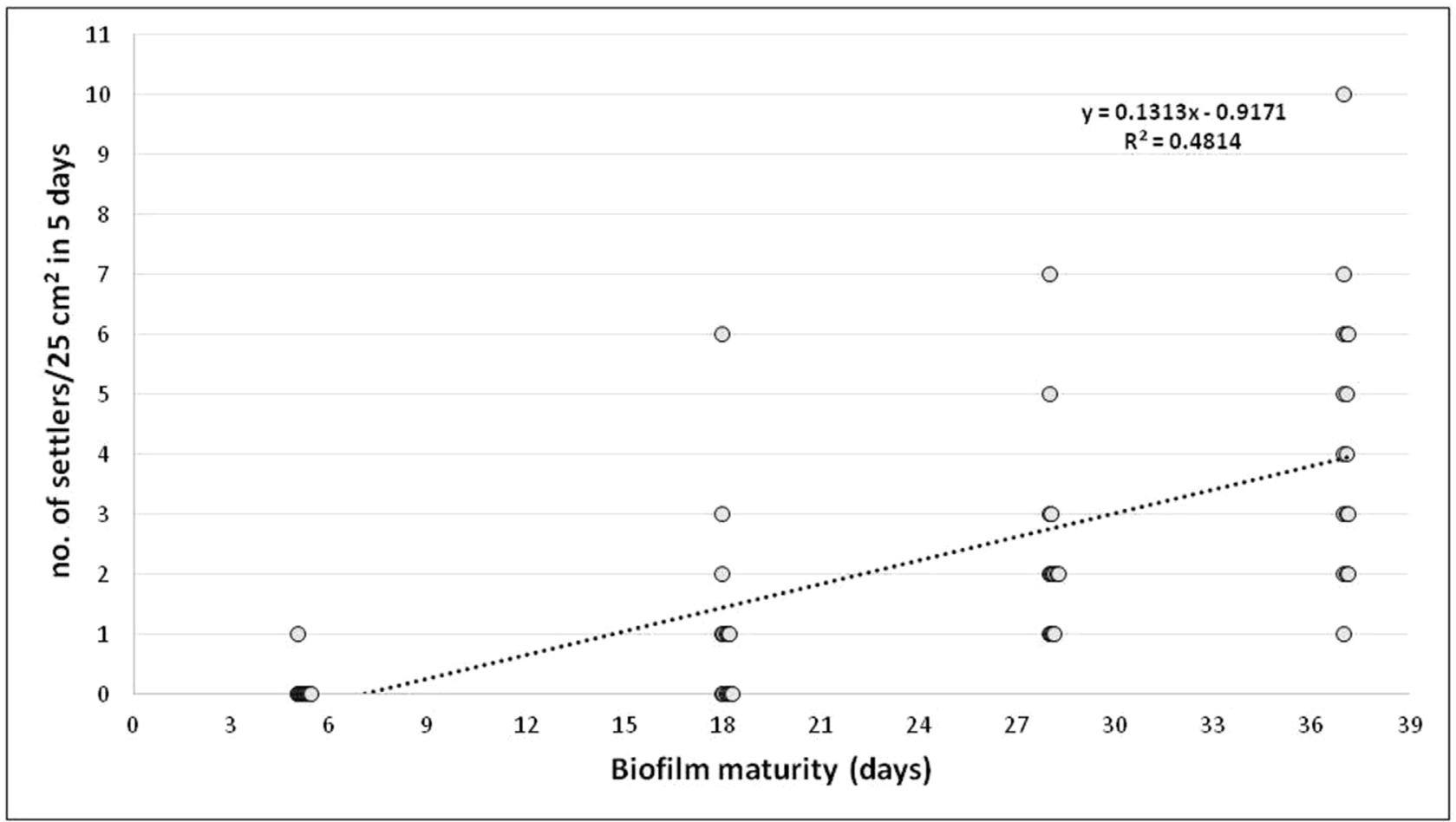

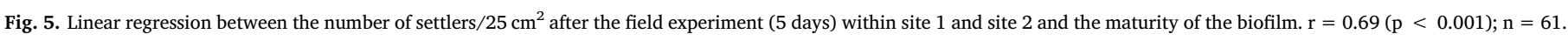

recorded on the two laboratory cultured biofilms than the field cultured ones. The two laboratory cultured biofilms did not differ each other and we recorded a low settlement rate on these substrates with on average less than 1 ind. $/ 25 \mathrm{~cm}^{2}$. Hence, it seems likely that the bacterial strains isolated from the reef-associated biofilm, although able to produce a film in most of the cases, did not succeed in promoting the settlement rate of $D$. cristatum during the field experiment. All the bacterial genera found within the reef-biofilm, Pseudoalteromonas spp., Alteromonas spp., Vibrio spp., Shewanella spp. and Cellulophaga spp., are frequently mentioned in marine biofilms as being able to affect larval settlement by multiple ways (Fitt et al., 1990; Kirchman et al., 1982; Satuito et al., 1995; Weiner et al., 1989; Yang et al., 2013). Pseudoalteromonas spp. and Alteromonas spp. received growing attention in biofilm-mediated settlement studies as bacteria which release settlement-inducing protein complex (SIPC) cueing larval metamorphosis of barnacle cyprids into competent settlers (Matsumura et al., 1998; Satuito et al., 1995). Pseudoalteromonas spp. had been subjected to detailed genetic and mechanistic studies (Freckelton et al., 2017), due to the widespread importance during the development of a variety of marine invertebrates (Huggett et al., 2006; Klassen et al., 2015). This bacterial genus has been also reported to affect the metamorphosis of the Caribbean coral nubbins (Negri et al., 2001; Sneed et al., 2014; Tebben et al., 2011), by the production of tetrabromopyrrole, an antibiotic compound which favours coral larvae against other competitors. Furthermore, the presence of metamorphosis associated contractile structures (MACs) on strains of Pseudoalteromonas luteoviolacea which trigger the settlement of the tubeworm $H$. elegans has also been described as responsible for the bacteria-larvae interaction (Shikuma et al., 2014). Alteromonas spp. and Vibrio spp. too are genera able to produce metamorphosis-inducing molecules (e.g. fatty acids) for hydroids, mussels and cnidarians and to induce gregarious larval settlement (De Gregoris et al., 2012; Leitz and Wagner, 1993; Neumann, 1979; Satuito et al., 1995). Cellulophaga lytica, moreover, is known to have outer-membrane vesicles (OMVs) involved in the bacteria-invertebrates interaction and responsible for inducing settlement of the tubeworm larvae (Freckelton et al., 2017).

By contrast, other researchers attribute to Vibrio spp. (e.g. Vibrio algynolithicus, Dobretsov and Quian, 2002), Alteromonas spp. and
Shewanella spp. the production of anti-fouling compounds (i.e. a polysaccharide $>200 \mathrm{kDa}$, proteases and an ubiquinone, Dobretsov et al., 2007; Harder et al., 2004; Kon-ya et al., 1995), which are deterrents to settlement of the polychaete Hydroides elegans and of the barnacle $B a$ lanus amphitrite.

This study shows the presence in the two artificially cultured biofilms of two Vibrio isolates, that may have inhibited the attachment of Dendropoma juveniles by proteases, largely produced by several Vibrio spp. (Salamone et al., 2015).

According to the results here obtained, the microbial associated stimulus responsible for cueing the settlement rate of the centralMediterranean Dendropoma cristatum seems to be age-dependent, either related to the increase of the biofilm density or to the settling of specific microbial taxa, although no taxon-specific responses, related to the culturable bacterial fraction, could be reported at this stage. However, it is known that culture-dependent techniques are able to isolate only a small fraction (i.e., less than the 1\%) of the whole microbial community of a natural environment (Hugenholtz, 2002). Hence in this study, the bacteria isolated from the reef-biofilm are only a small fraction of the total microbial assemblage that could have a positive effect on the settlement and the influence of non-cultivable bacteria can not be excluded. Furthermore, the employment of additional culture-media and incubating conditions is of course an option to improve the range of cultivable bacteria from the vermetid reef-associated biofilm (Joint et al., 2010).

However, our study represents the first attempt to assess the biodiversity of vermetid reef-associated cultivable bacteria and the potential role of the biofilm ageing in affecting the settlement of the reefbuilders $D$. cristatum. Overall, biofilm age is strongly linked to microbial succession and significantly increased bacterial density, with pioneering biofilms generally supporting a low diversity of immediate colonisers and established biofilms comprising a higher diversity of bacteria and other single-celled microorganisms (Dang and Lovell, 2016). Studies focusing on the successional patterns of marine biofilms report that microbial films progress toward complex 3-dimensional fouling layers, with variations also in the biological composition and the metabolic activity of their components (MacLulich, 1986; Nagarkar, 
1996). Importantly, mature biofilms support a matrix of complex molecules and morphogenic signaling compounds which are thought to contribute to larval settlement in marine invertebrate species (Hadfield, 2011). This matrix shows great microheterogeneity, within which numerous microenvironments can exist (Sutherland, 2001). Trying to explain the bacterial succession on the artificial settlement blocks used in this study is not easy at this step of the research. Overall, the dynamics of surface colonization in the marine environment, particularly in the early stages of biofilm formation are not well understood and are characterized by transient attachment periods or competition between species (Siboni et al., 2007). Successional patterns are dependent on the nature of the substratum, water flow, concentrations of organic macromolecules as well as the availability of bacteria, algal spores and invertebrate larvae. Generally, in temperate climates, biofilms reach a maximum development during the summer and decreases significantly during the winter months, as a result of reduced temperature, lower light intensity and shorter day-length (Charaklis, 1981; Valiela, 1995). After adsorption of organic molecules onto a surface, bacteria are generally the earliest colonizers (Chan et al., 2003), as they are the microorganisms immediately able to consume these organics (Bakker et al., 2004; Bhosle et al., 2005; Siboni et al., 2007). Bacteria are followed by diatoms, cyanobacteria and, in the late stages, encrusting algae. Studies conducted in temperate coastal marine waters show that the Rhodobacterales (Alphaproteobacteria) are the most representative bacterial group of early -colonizers on natural and artificial surfaces (Dang and Lovell, 2000; Dang et al., 2008; Jones et al., 2007) and Planctomycetes are associated with a more mature community (Brummer et al., 2004; Chung et al., 2010), although bacterial succession is strongly affected by local conditions.

These successional biofilm community changes may affect larval settlement in many ways (Wieczorek and Todd, 1997). In our study, substratum physical variations associated with the presence of a welldeveloped microbial layer could be perceived by the crawling Dendropoma juveniles as a cue which indicates higher habitat heterogeneity (Sutherland, 2001) and availability of resources for their early development. Beside, bio-molecular stimuli from mature biofilms may promote the juvenile's cementation to the substratum and recruitment by morphogenetic way, as in the case of other intertidal ecosystem engineers, such as: mussels (Tamburri et al., 2008), barnacles (Thompson et al., 1998) and polychaetes (Hadfield, 2011; Zardus et al., 2008).

The clear differences in the settlement rates observed on different biofilm treatments support the conclusion that crawling $D$. cristatum are able to actively select their settlement substratum. This hypothesis was also sustained by Spotorno-Oliveira et al. (2015) which showed that the Brazilian reef builders Dendropoma irregulare selects living crustose coralline algae (CCA) (i.e., Porolithon pachydermum) as settlement substratum. In the study, the presence of a biofilm associated to CCA was only hypothesized as a biological stimulus potentially enhancing the vermetid settlement (Spotorno-Oliveira et al., 2015). Here we suggest that an older microbial community can trigger vermetid settlement, showing another biogenic cue that could have implication in the vermetid settlement. However, further research is needed to fully elucidate these heterospecific positive interactions.

An additional interesting outcome of our study may be the use of limestone, which is the natural settlement rock for D. cristatum (Antonioli et al., 1999). Settlement experiments are seldom conducted under natural conditions and on natural rocks (Thompson et al., 1998). Artificial materials, such as plastic plates and glass microscope slides (e.g. Todd and Keough, 1994), are largely employed for microbial film and marine larvae attachment, and this may considerably influence the settlement patterns (Henschel et al., 1990; Mihm et al., 1981; Wahl, 1989). In this study, the high number of $D$. cristatum settlers recorded on the limestone blocks after 5 days of field exposure (on average $1.41 \pm 0.22$ ind. $/ 25 \mathrm{~cm}^{2}$ ) is consistent with previous settlement rate data recorded on natural vermetid reefs in a different site in the NW of Sicily (Franzitta et al., 2016). Therefore, we suggest limestone to be a suitable substrate for the settlement of this reef-building species with potential outcomes for restoration actions. To our knowledge, restoration of Dendropoma spp. reefs has not occurred before and the lack of knowledge about the biology of these reef-builder vermetids critically hinders the development of such a practice (Milazzo et al., 2016). Once anthropogenic pressures affecting Dendropoma spp. survival at local scale (e.g. Di Franco et al., 2011) are removed by active management and protection measures, we suggest the transplantation of such Dendropoma-colonized blocks could be an option to promote reef recovery and restoration and thus to potentially invert the observed decline of some reefs in the Western Mediterranean. Studies including the assessment of settlement stage of other Mediterranean Dendropoma species are strongly needed to promote valid management plans of these intertidal reefs at a more regional level, particularly on those population facing ongoing decline (Galil, 2013; Rilov, 2013, 2016).

Finally, this research might also provide some useful insights about the biological interactions with bacterial films which may be of relevance for successful reef development. Likely specific properties of an aged biofilm may affect habitat selection by Dendropoma cristatum crawling juveniles, improving their settlement rate. To fully elucidate the role of the biofilm in the settlement process of this vermetid species, a more detailed description of the total microbial community composition, along with abundances and types of algae and protozoa as well as other bacteria, would be a useful addition to the present study. To achieve this aim, fingerprinting techniques and high throughput DNA sequencing of the microbial assemblages are in progress, as the following step for this research.

\section{Acknowledgements}

The authors thank Dr. Elena Galia and Dr. Marcello Tagliavia for technical support in bacterial isolation and identification.

\section{References}

Agate, M., Basilone, L., Di Maggio, C., Contino, A., Pierini, S., Catalano, R., 2017. Quaternary marine and continental unconformity-bounded stratigraphic units of the NW Sicily coastal belt. J. Maps 13, 425-437.

Antonioli, F., Chemello, R., Improta, S., Riggio, S., 1999. Dendropoma lower intertidal reef formations and their palaeoclimatological significance (NW Sicily). Mar. Geol. 161, 155-170.

Bakker, D.P., Busscher, H.J., Zanten, J.V., Vriesm, J.D., Klijnstra, J.W., Van Der Mei, H.C., 2004. Multiple linear regression analysis of bacterial deposition to polyurethane coatings after conditioning film formation in the marine environment. Microbiology 150, 1779-1784.

Basilone, L., Di Maggio, C., 2016. Geology of Monte gallo (Palermo mts, NW sicily). J. Maps 12, 1072-1083. http://dx.doi.org/10.1080/17445647.2015.1124716.

Barbier, E.B., Hacker, S.D., Kennedy, C., Koch, E.W., Stier, A.C., Silliman, B.R., 2011. The value of estuarine and coastal ecosystem services. Ecol. Monogr. 81 (2), 169-193.

Bertness, M.D., Callaway, R., 1994. Positive interactions in communities. Trends Ecol. Evol. 9 (5), 191-193.

Bertolini, C., Geraldi, N.R., Montgomery, W.I., O'Connor, N.E., 2017. Substratum type and conspecific density as drivers of mussel patch formation. J. Sea Res. 121, 24-32.

Bhosle, N.B., Garg, A., Fernandes, L., Citon, P., 2005. Dynamics of amino acids in the conditioning.lm developed on glass panels immersed in the surface seawaters of Dona Paula Bay. Biofouling 21, 99-107.

Brummer, I.H.M., Felske, A.D.M., Wagner-Dobler, I., 2004. Diversity and seasonal changes of uncultured Planctomycetales in river biofilms. Appl. Environ. Microbiol. 70, 5094-5101.

Bruno, J.F., Stachowicz, J.J., Bertness, M.D., 2003. Inclusion of facilitation into ecological theory. Trends Ecol. Evol. 18 (3), 119-125.

Calvo, M., Alda, F., Oliverio, M., Templado, J., Machordom, A., 2015. Surviving the messinian salinity Crisis? Divergence patterns in the genus Dendropoma (gastropoda: Vermetidae) in the Mediterranean Sea. Mol. Phylogenet. Evol. 91, 17-26.

Calvo, M., Templado, J., Oliverio, M., Machordom, A., 2009. Hidden Mediterranean biodiversity: molecular evidence for a cryptic species complex within the reefbuilding gastropod Dendropoma petraeum (Mollusca: Caenogastropoda). Biol. J. Linn. Soc. 96 (4), 898-912.

Calvo, M., Templado, J., Penchaszadeh, P.E., 1998. Reproductive biology of the gregarious Mediterranean vermetid gastropod Dendropoma petraeum. J. Mar. Biol. Assoc. U. K. 78, 525-549.

Catania, V., Sarà, G., Settanni, L., Quatrini, P., 2017. Bacterial communities in sediment of a Mediterranean marine protected area. Can. J. Microbiol. 63, 303-311.

Catania, V., Santisi, S., Signa, G., Vizzini, S., Mazzola, A., Cappello, S., Yakimov, M.M., Quatrini, P., 2015. Intrinsic bioremediation potential of a chronically polluted marine 
coastal area. Mar. Pollut. Bull. 99 (1-2), 138-149.

Charaklis, W.G., 1981. Fouling biofilm development: a process analysis. Biotechnol. Bioeng. 23, 1923-1960.

Chemello, R., Giacalone, A., La Marca, E.C., Templado, J., Milazzo, M., 2014. Distribution and conservation needs of a neglected ecosystem: the Mediterranean Vermetid Reef. In: 2nd Mediterranean Symposium on the Conservation of Coralligenous and Other Calcareous Bio-concretions (Portorož, Slovenia, 29-30 October).

Chemello, R., 2009. Marine bioconstructions in the Mediterranean Sea. A state-of-the-art on the vermetid reef. Biol. Mar. Mediterr. 16 (1), 2-18.

Chan, B.B.K., Wallis, K.S., Walker, G., 2003. Patterns of biofilm succession on a sheltered rocky shore in Hong Kong. Biofouling 19 (6), 371-380.

Chung, H.C., Lee, O.O., Huang, Y.L., Mok, S.Y., Kolter, R., Qian, P.Y., 2010. Bacterial community succession and chemical profiles of subtidal biofilms in relation to larval settlement of the polychaete Hydroides elegans. ISME J. 4, 817-828.

Cole, J.R., Wang, Q., Fish, J.A., Chai, B., McGarrell, D.M., Sun, Y., Brown, C.T., Porras Alfaro, A., Kuske, C.R., Tiedje, J.M., 2014. Ribosomal Database Project: data and tools for high throughput rRNA analysis. Nucl. Acids Res. 41 (Database issue), D633-D642.

Costanza, R., D'Arge, R., De Groot, R., Farber, S., Grasso, M., Hannon, B., Limburg, K., Naeem, S., Oneill, R.V., Paruelo, J., Raskin, R.G., Sutton, P., Van den Belt, M., 1997. The value of the world's ecosystem services and natural capital. Nature 387, 253-260.

Crisp, D.J., 1974. Factors influencing the settlement of marine invertebrate larvae. In: Grant, P.T., Mackie, A.M. (Eds.), Chemoreception in Marine Organisms. Academic Press, London, pp. 177-265.

Crossland, C.J., Kremer, H.H., Lindeboom, H.J., Marshall, J.I., Le Tissier, M.D.A., 2005 In: Coastal Fluxes in the Antrhopocene. Springer $232 \mathrm{pp}$.

Dang, H., Lovell, C.R., 2016. Microbial surface colonization and biofilm development in marine environments. Microbiol. Mol. Biol. Rev. 80, 91-138. http://dx.doi.org/10. 1128/MMBR.00037-15.

Dang, H.Y., Li, T.G., Chen, M.N., Huang, G.Q., 2008. Cross-Ocean distribution of Rhodobacterales bacteria as primary surface colonizers in temperate coastal marine waters. Appl. Environ. Microbiol. 74, 52-60.

Dang, H.Y., Lovell, C.R., 2000. Bacterial primary colonization and early succession on surfaces in marine waters as determined by amplified rRNA gene restriction analysis and sequence analysis of 16S rRNA genes. Appl. Environ. Microbiol. 66, 467-475.

De Gregoris, T.B., Khandeparker, L., Anil, A.C., Meshbahi, E., Burgess, J.G., Clare, A.S. 2012. Characterisation of the bacteria associated with barnacle Balanus amphitrite shell and their role in gregarious settlement of cypris larvae. J. Exp. Mar. Biol. Ecol. 413, 7-12.

Di Franco, A., Graziano, M., Franzitta, G., Felline, S., Chemello, R., Milazzo, M., 2011. Do small marinas drive habitat specific impacts? A case study from Mediterranean Sea. Mar. Pollut. Bull. 62, 926-933.

Di Maggio, C., Agate, M., Contino, A., Basilone, L., Catalano, R., 2009. Unconformitybounded stratigraphic units of quaternary deposits mapped for the CARG project in northern and western Sicily [unità a limiti inconformi utilizzate per la cartografia dei depositi quaternari nei fogli CARG della sicilia nord-occidentale]. Alpine Mediterr. Quat. 22, 345-364 (Open Access).

Dobretsov, S.V., Xiong, H., Xu, Y., Levin, L.A., Quian, P.Y., 2007. Novel antifoulants: inhibition of larval attachment by proteases. Mar. Biotechnol. 9, 388-397.

Dobretsov, S.V., Quian, P.Y., 2002. Effect of bacteria associated with the green alga Ulva reticulate on marine micro- and macrofouling. Biofouling 18, 217-228.

Donlan, R.M., 2002. Biofilms: microbial life on surfaces. Emerg. Infect. Dis. 8, 881-890.

Fine, M., Tsadok, R., Meron, D., Cohen, S., Milazzo, M., 2016. Environmental sensitivity of Neogoniolithon brassica-florida associated with vermetid reefs in the Mediterranean Sea. ICES J. Mar. Sci. 74 (4), 1074-1082.

Firth, L.B., Mieszkowska, N., Grant, L.M., Bush, L.E., Davies, A.J., Frost, M.T., Moschella, P.S., Burrows, M.T., Cunningham, P.N., Dye, S.R., Hawkins, S.J., 2015. Historical comparisons reveal multiple drivers of decadal change of an ecosystem engineer at the range edge. Ecol. Evol. 5 (15), 3210-3222. https://doi.org/10.1002/ece3.1556.

Fitt, W.K., Coon, S.L., Walch, M., Weiner, R.M., Colwell, R.R., Bonar, D.B., 1990. Settlement behavior and metamorphosis of oyster larvae (Crassostrea gigas) in response to bacterial supernatants. Mar Biol. 106, 389-394.

Franzitta, G., Capruzzi, E., La Marca, E.C., Milazzo, M., Chemello, R., 2016. Recruitment patterns in an intertidal species with low dispersal ability: the reef-building Dendropoma cristatum (Biondi, 1859) (Mollusca: gastropoda). Ital. J. Zool. 83 (3), 400-407.

Freckelton, M.L., Nedved, B.T., Hadfield, M.G., 2017. Induction of invertebrate larval settlement; different bacteria, different mechanisms? Sci. Rep. 7, 42557. http://dx. doi.org/10.1038/srep42557.

Galil, B.S., 2013. Going going gone: the loss of a reef-building gastropod (Mollusca: gastropoda: Vermetidae) in the Mediterranean Sea. Zool. Middle East 59 (2), 179-182.

Golding, R.E., Bieler, R., Rawlings, T.A., Collins, T.M., 2014. Deconstructing Dendropoma: a systematic revision of a world-wide worm-snail group with description of new genera (Caenogastropoda: Vermetidae). Malacologia 57 (1), 1-97.

Grabowski, J.H., Peterson, C.H., 2007. Restoring oyster reefs to recover ecosystem services. Theor. Ecol. Ser. 4, 281-298.

Green, D., Boots, B., O'Connor, N.E., Thompson, R., 2016. Microplastics affect the ecological functioning of an important biogenic habitat. Environ. Sci. Technol. 51 (1), 68-77. https://doi.org/10.1021/acs.est.6b04496.

Hadfield, M.G., 2011. Biofilm and marine invertebrate larvae: what bacteria produce that larvae use to choose settlement sites. Annu. Rev. Mar. Sci. 3, 453-470.

Hadfield, M.G., Paul, V.J., 2001. Natural chemical cues for settlement and metamorphosis of marine invertebrate larvae. In: McClinTOCk, J.B., Baker, B.J. (Eds.), Marine Chemical Ecology. CRC Press, pp. 431-461.

Harder, T., Dobretsov, S., Qian, P.Y., 2004. Waterborne polar macromolecules act as algal antifoulants in the seaweed Ulva reticulate. Mar. Ecol. Prog. Ser. 274, 133-141.

Henschel, J.R., Branch, G.M., Cook, P.A., 1990. The colonisation of artificial substrata by marine sessile organisms in False Bay. 2. Substratal material. J. Mar. Sci. 9, 299-307.

Hugenholtz, P., 2002. Exploring prokaryotic diversity in the genomic era. Genome Biol. 3 Reviews0003.

Huggett, M., Williamson, J., de Nys, R., Kjelleberg, S., Steinberg, P., 2006. Larval settlement of the common Australian sea urchin Heliocidaris erythrogramma in response to bacteria from the surface of coralline algae. Oecologia 149, 604-619.

Joint, I., Mühling, M., Querellou, J., 2010. Culturing marine bacteria - an essential prerequisite for biodiscovery. Microb. Biotechnol. 3, 564-575.

Jones, P.R., Cottrell, M.T., Kirchman, D.L., Dexter, S.C., 2007. Bacterial community structure of biofilms on artificial surfaces in an estuary. Microb. Ecol. 53, 153-162.

Jones, C.G., Lawton, J.H., Shachak, M., 1997. Positive and negative effects of organisms as physical ecosystem engineers. Ecology 78, 1946-1957.

Keough, M.J., Raimondi, P.T., 1996. Responses of settling invertebrate larvae to bioorganic films: effects of large-scale variation in films. J. Exp. Mar. Biol. Ecol. 207 (1-2), 59-78. http://dx.doi.org/10.1016/5022-0981(96)02632-9.

Keough, M.J., Raimondi, P.T., 1995. Responses of settling invertebrate larvae to bioorganic films - effects of different types of films. J. Exp. Mar. Biol. Ecol. 185 (2), 235-253. http://dx.doi.org/10.1016/00222-0981(94)00154-6.

Kirchman, D., Graham, S., Reish, D., Mitchell, R., 1982. Bacteria induce settlement and metamorphosis of Janua (Dexiospira) brasiliensis Grube (Polychaeta: Spirorbidae). J. Exp. Mar. Biol. Ecol. 56, 153-163.

Klassen, J.L., Wolf, T., Rischer, M., Guo, H., Shelest, E., Clardy, J., Beemelmanns, C., 2015. Draft genome sequences of six Pseudoalteromonas strains, P1-7A, P1-9, P1-13 1A, P1-16-1B, P1-25, AND P1-26, which induce larval settlement and metamorphosis in Hydractinia echinata. Genome Announc. 3 (6). http://dx.doi.org/10.1128/ genomeA.01477-15. e01477-15.

Kon-ya, K., Shimidzu, N., Otaki, N., Yokoyama, A., Addachi, K., Miki, W., 1995. Inhibitory effect of bacterial ubiquinones on the settling of barnacle, Balanus amphitrite. Cell. Mol. Life Sci. 51, 153-155.

Laborel, J., 1987. Marine biogenic constructions in the Mediterranean. A review. Sci. Rep. of Port-Cros National Park 13, 97-126.

Leitz, T., Wagner, T., 1993. The marine bacterium Alteromonas espejiana induces metamorphosis of the hydroid Hydractina echinata. Mar. Biol. 115 (2), 173-178.

MacLulich, J.H., 1986. Expenmental evaluation of methods for sampling and assaying intertidal epilithic microalgae. Mar. Ecol. Prog. Ser. 34, 275-280.

Matsumura, K., Nagano, M., Fusetani, N., 1998. Purification of a larval settlement-inducing protein complex (SIPC) of the barnacle, Balanus amphitrite. J. Exp. Zool. 281, $12-20$.

Menge, B.A., 2000. Top-down and bottom-up community regulation in marine rocky intertidal habitats. J. Exp. Mar. Biol. Ecol. 250, 257-289.

Mihm, J.W., Banta, W.C., Loeb, G.I., 1981. Effects of adsorbed organic and primary fouling films on bryozoan settlement. J. Exp. Mar. Biol. Ecol. 54, 167-179.

Milazzo, M., Fine, M., La Marca, E.C., Alessi, C., Chemello, R., 2016. Drawing the line at neglected marine ecosystems: ecology of vermetid reefs in a changing ocean. In Rossi, S., Bramanti, L., Gori, A., Orejas Saco del Valle, C. (Eds.), Marine Anima Forests, the Ecology of Benthic Biodiversity Hotspots. Springer International Publishing, 978-3-319-21011-7, pp. 345-367.

Milazzo, M., Rodolfo-Metalpa, R., Bin San Chan, V., Fine, M., Alessi, C., Thiyagarajan, V., Hall-Spencer, J.M., Chemello, R., 2014. Ocean acidification impairs vermetid reef recruitment. Sci. Rep. 4, 4189. http://dx.doi.org/10.1038/srep04189.

Nagarkar, S., 1996. The Ecology of Intertidal Epilithic Biofilms with Special Reference to Cyanobacteria. PhD thesis. University of Hong Kong.

Negri, A.P., Webster, N.S., Hill, R.T., Heyward, A.J., 2001. Metamorphosis of broadcast spawning corals in response to bacteria isolated from crustose algae. Mar. Ecol. Prog. Ser. 223, 121-131.

Neumann, R., 1979. Bacterial induction of settlement and metamorphosis in the Planula larvae of Cassiopea andromeda (Cnidaria: scyphozoa, Rhizostomeae). Mar. Ecol. Prog. Ser. 1, 21-28.

Olivier, F., Tremblay, R., Bourget, E., Rittschof, D., 2000. Barnacle settlement: field experiments on the influence of larval supply, tidal level, biofilm quality and age on Balanus amphitrite cyprids. Mar. Ecol. Prog. Ser. 199, 185-204.

Pawlik, J.R., 1992. Chemical ecology of the settlement of benthic marine invertebrates, Ocean. Mar. Biol. Ann. Rev. 30, 273-335.

Phillips, N.E., 2011. Where are larvae of the vermetid gastropod Dendropoma maximum on the continuum of larval nutritional strategies? Mar. Biol. 158, 2335-2342.

Qian, P.Y., Lau, S.C.K., Dahms, H.U., Dobretsov, S., Harder, T., 2007. Marine biofilms as mediators of colonization by marine macroorganisms: implications for antifouling and aquaculture. Mar. Biotechnol. 9, 399-410.

Rilov, G., 2016. Multi-species collapses at the warm edge of a warming sea. Sci. Rep. 6, 36897. http://dx.doi.org/10.1038/srep36897.

Rilov, G., 2013. Regional extinctions and invaders' domination: an ecosystem phase-shift of Levant reefs. Rapport de la Commission Internationale pour l'Exploration Scientifique de la Mér Méditerranée 40, 782-783.

Safriel, U., 1966. Recent vermetid formation on the Mediterranean shore of Israel. Proc. Malacol. Soc. Lond. 37, 27-34.

Salamone, M., Nicosia, A., Bennici, C., Quatrini, P., Catania, V., Mazzola, S., Ghersi, G., Cuttitta, A., 2015. Comprehensive analysis of a Vibrio parahaemolyticus strain extracellular serine protease VpSP37. PLoS One 10 (7). http://dx.doi.org/10.1371/ journal.pone.0126349. e0126349.

Satuito, C.G., Shimizu, K., Fusetani, N., 1997. Studies on the factors influencing larval settlement in Balanus amphitrite and Mytilus galloprovincialis. In: Hagiwara, A., Snell, T.W., Lubzens, E., Tamaru, C.S. (Eds.), Live Food in Aquaculture. Developments in Hydrobiology. Springer, Dordrecht, pp. 275-280.

Satuito, C.G., Natoyama, K. Yamazaki, M., Fusetani, N., 1995. Induction of attachment 
and metamorphosis of laboratory cultured mussel Mytilus galloprovincialis larvae by microbial film. Fish. Sci. 61, 223-227.

Sharp, K.H., Sneed, J.M., Ritchie, K.B., Mcdaniel, L., Paul, V.J., 2015. Induction of larval settlement in the reef coral Porites astreoides by a cultivated marine Roseobacter strain. Biol. Bull. 228, 98-107.

Shikuma, N.J., Pilhofer, M., Weiss, G.L., Hadfield, M.G., Jensen, G.J., Newman, D.K., 2014. Marine tubeworm metamorphosis induced by arrays of bacterial phage taillike structures. Science 31, 529-533. http://dx.doi.org/10.1126/science.1246794.

Siboni, N., Lidor, M., Kramarsky-Winter, E., Kushmaro, A., 2007. Conditioning film and initial biofilm formation on ceramics tiles in the marine environment. Fed. Eur. Microbiol. Soc. 274, 24-29.

Sneed, J.M., Sharp, K.H., Ritchie, K.B., Paul, V.J., 2014. The chemical cue tetrabromopyrrole from a biofilm bacterium induces settlement of multiple Caribbean corals. Proc. R. Soc. Ser. B 281, 1786.

Spotorno-Oliveira, P., Figueiredo, M.A.O., Tâmega, F.T.S., 2015. Coralline algae enhance the settlement of the vermetid gastropod Dendropoma irregulare (d'Orbigny, 1842) in the southwestern Atlantic. J. Exp. Mar. Biol. Ecol. 471, 137-145.

Stachowicz, J.J., 2001. Mutualism, facilitation, and the structure of ecological communities. Bioscience 51 (3), 235-246.

Stepanović, S., Ćirković, I., Ranin, L., Švabić-Vlahović, M., 2004. Biofilm formation by Salmonella spp. and Listeria monocytogenes on plastic surface. Lett. Appl. Microbiol. 38, 428-432.

Sutherland, I., 2001. The biofilm matrix-an immobilized but dynamic microbial environment. Trends Microbiol. 9 (5), 222-227.

Tamburri, M.N., Luckenbach, M.W., Breitburg, D.L., Bonniwell, S.M., 2008. Settlement of Crassostrea ariakensis larvae: effects of substrate, biofilms, sediment and adult chemical cues. J. Shellfish Res. 27, 601-608.

Tebben, J., Tapiolas, M.D., Motti, C.A., Abrego, D., Negri, A.P., Blackall, L.L., Steinberg, P.D., Harder, T., 2011. Induction of larval metamorphosis of the coral Acropora millepora by tetrabromopyrrole isolated from a Pseudoalteromonas bacterium. PLoS One 6 (4), e19082. http://dx.doi.org/10.1371/journal.pone.0019082.

Templado, J., Richter, A., Calvo, M., 2016. Reef building Mediterranean vermetid gastropods: disentangling the Dendropoma petraeum species complex. Mediterr. Mar. Sci. 17 (1), 13-31.

Thompson, R.C., Norton, T.A., Hawkins, S.J., 1998. The influence of epilithic microbial films on the settlement of Semibalanus balanoides cyprids - a comparison between laboratory and field experiments. Hydrobiologia 375, 203-216.

Todd, C.D., Keough, M.J., 1994. Larval settlement in hard substratum epifaunal assemblages: a manipulative field study of the effects of substratum filming and the presence of incumbents. J. Exp. Mar. Biol. Ecol. 181, 159-187.

Toupoint, N., Mohit, V., Linossier, I., Bourgougnon, N., Myrand, B., Olivier, F., Lovejoy, C., Tremblay, R., 2012. Effect of biofilm age on settlement of Mytilus edulis. Biofouling: J. Bioadhesion Biofilm Res. 28 (9), 985-1001.

Underwood, A.J., Denley, E.J., Moran, M.J., 1983. Experimental analyses of the structure and dynamics of mid-shore rocky intertidal communities in New South Wales. Oecologia 56, 202-219.

Valiela, I. (Ed.), 1995. Maine Ecological Processes. Springer-Verlag, New York, 978-14757-4125-4, pp. 686.

Vieira, C., Engelen, A.H., Guentas, L., Aires, T., Houlbreque, F., Gaubert, J., Serrão, E.A., De Clerck, O., Payri, C.E., 2016. Species specificity of bacteria associated to the Brown seaweeds lobophora (Dictyotales, Phaeophyceae) and their potential for induction of rapid coral bleaching in Acropora muricata. Front. Microbiol. 7, 316. http://dx.doi.org/10.3389/fmicb.2016.00316.

Wahl, M., 1989. Marine epibiosis. I. Fouling and antifouling: some basic aspects. Mar. Ecol. Progr. Ser. 58, 1-2.

Webster, N.S., Soo, R., Cobb, R., Negri, A.P., 2011. Elevated seawarer temperature causes a microbial shift on crustose coralline algae with implications for the recruitment of coral larvae. ISME J. 5, 759-770.

Webster, N.S., Smith, L.D., Heyward, A.J., Watts, J.E.M., Webb, R.I., Blackall, L.L., Negri, A.P., 2005. Metamorphosis of a scleractinian coral in response to microbial biofilms. Appl. Environ. Microbiol. 70 (2), 1213-1221.

Weiner, R.M., Walch, M., Labare, M.P., Bonar, D.B., Colwell, R.R., 1989. Effect of biofilms of the marine bacterium Alteromonas colwelliana (LST) on settlement of the oysters Crassostrea gigas (Thunberg, 1793) and C. virginica (Gmelin, 1791). J. Shellfish Res. 8 (1), 117-123.

Whalan, S., Webster, N.S., 2014. Sponge larval settlement cues: the role of microbial biofilms in a warming ocean. Sci. Rep. 4, 4072. http://dx.doi.org/10.1038/ srep04072.

Wieczorek, S.K., Todd, C.D., 1998. Inhibition and facilitation of settlement of epifaunal marine invertebrate larvae by microbial biofilm cues. Biofouling 12, 81-118.

Wieczorek, S.K., Todd, C.D., 1997. Inhibition and facilitation of bryozoan and ascidian settlement by natural multispecies biofilms: effects of film age and the roles of active and passive larval attachment. Mar. Biol. 128, 463-473.

Yang, J.L., Shen, P.J., Liang, X., Li, Y.F., Bao, W.Y., Li, J.L., 2013. Larval settlement and metamorphosis of the mussel Mytilus coruscus in response to monospecific bacterial biofilms. Biofouling 29 (3), 247-259.

Zardus, J.D., Nedved, B.T., Huang, Y., Tran, C., Hadfield, M.G., 2008. Microbial film facilitate adhesion in biofouling invertebrates. Biol. Bull. 214, 91-98. 